\title{
Minimally invasive lift of the middle third of the face using musculoaponeurotic suspension with periosteal fixation technique: a review of 50 cases
}

\author{
Suspensão musculoaponeurótica com fixação periostal minimamente invasiva do \\ terço médio da face: revisão de 50 casos
}

Alexandre Silveira Timóteo DE SOUZA ${ }^{1}$

Jỗo Carlos Cisneiros Guedes de Andrade Júnior ${ }^{2}$

Study conducted at Surface Cosmetic Anti-Aging Clinic, Charleston, WV, USA, and in the Health Institute of the Woman, Belo Horizonte, MG, Brazil.

Submitted to SGP (Sistema de Gestão de Publicações/Manager Publications System) of RBCP (Revista Brasileira de Cirurgia

Plástica/Brazilian Journal of Plastic Surgery).

Received: December 3, 2010 Accepted: August 13, 2011

\begin{abstract}
Background: At present, demanding workplaces in our society cause patients to search for less invasive procedures with diminished morbidity and more rapid healing to meet their cosmetic requirements. A combination of several new noninvasive procedures allows significant facial changes, achieving a youthful and healthy appearance without traditional surgical procedures. Objective: The purpose of this study is to describe the minimally invasive lift of the middle third of the face using a musculoaponeurotic suspension with periosteal fixation technique. Methods: Fifty patients (age, 39 to 68 years; all female) who underwent an operation from December 2008 to June 2010 were enrolled in this study. The patients underwent a minimally invasive facelift technique for the middle third of the face, based on a thread lift of the temporal region and musculoaponeurotic suspension with periosteal fixation, inside the hairline. Results: During the follow-up period of up to 18 months after the procedure, satisfactory results were observed. The patient satisfaction degree, especially in the first 6 months after the procedure, was extremely high (88\%). Conclusions: The procedure offers good and immediate results, without incisions or a recovery period. The association of this procedure with other procedures is a good option for patients who cannot undergo or do not want to undergo traditional surgical procedures. The procedure is very different from current techniques that use threads because the suspension is musculoaponeurotic and does not invade the face. Therefore, morbidity and recovery time are decreased.
\end{abstract}

Keywords: Face/surgery. Surgical procedures, minimally invasive. Rejuvenation.

\section{RESUMO}

Introdução: Na sociedade atual, em decorrência das demandas profissionais, os pacientes cada vez mais procuram por procedimentos menos invasivos, com baixa morbidade, rápida recuperação, e que atendam a suas preocupações estéticas. Uma combinação de vários novos procedimentos nãoinvasivos permite mudanças faciais significativas e aparência jovem e saudável, sem a utilização de procedimentos cirúrgicos tradicionais. Objetivo: O objetivo deste estudo é a descrição de técnica de suspensão musculoaponeurótica com fixação periostal minimamente invasiva do terço médio da face. Método: Foram incluídos nesse estudo 50 pacientes, com idades entre 39 anos e 68 anos, todos do sexo feminino, operados no period de dezembro de 2008 a junho de 2010 . As pacientes foram submetidas à realização de facelift minimamente invasivo do terço médio da face, com suspensão musculoaponeurótica com fixação periostal, baseado na tração com fio passado na região temporal, dentro da área do cabelo. Resultados: No acompanhamento das pacientes, até 18 meses após a realização do procedimento, verificaram-se resultados satisfatórios. O grau de satisfação das pacientes com os resultados obtidos, principalmente nos primeiros seis meses após a realização do procedimento, foi extremamente alto $(88 \%)$. Conclusões: $O$ procedimento ofereceu bons e imediatos resultados, sem incisões ou período de recuperação. Associado a outros procedimentos de rejuvenescimento facial, trata-se de boa opção a pacientes que não podem ou não querem se submeter a procedimentos cirúrgicos tradicionais. O procedimento difere significativamente das técnicas atuais que usam fios, pois a suspensão é musculoaponeurótica e não invade a área da face, o que diminui a morbidade e o período de recuperação.

Descritores: Face/cirurgia. Procedimentos cirúrgicos minimamente invasivos. Rejuvenescimento.

1. Plastic Surgeon, Chairman of the Skin \& Wound Healing Services at Roane General Hospital, Spencer, WV, USA, and Clinical Director of the Surface Cosmetic Anti-Aging Clinic, Charleston, WV, USA.

2. Plastic surgeon, specialist member of the Brazilian Society for Plastic Surgery, and member Clinical Staff of the Health Institute of the Woman, Belo Horizonte, MG, Brazil. 


\section{INTRODUCTION}

The appearance of the face is fundamental to human interpersonal perception and often undergoes the aging process. Classically, the causes of aging are divided into biological (intrinsic) and extrinsic factors, such as sun and environmental exposures. The clinical outcome of the aging process is skin sagging, deepening of expression lines, dryness and flattening of the dermoepidermal junction, with significant changes in color, texture, and quality of the skin ${ }^{1,2}$.

The American Society for Plastic Surgery has estimated that more than 117,000 facelift procedures are performed each year in the United States ${ }^{3}$.

In his book "Handbuch der Kosmetik" (1912), Hollander described a procedure very similar to the facelift that is performed today. Hollander may have performed the first facelift on an aristocrat in the year $1901^{4}$. In 1906, Lexer reported facial surgery performed on an actress. The procedure and its results were considered revolutionary ${ }^{5}$.

Because of the workplace demands in today's society, patients are increasingly looking for less invasive procedures that have low morbidity, rapid recovery time, and meet their esthetic concerns ${ }^{6}$. The combined use of several new noninvasive procedures allows significant facial changes that result in a healthy and younger appearance, without the use of traditional surgical procedures.

The use of suspension procedures and suspension threads on the face is not recent ${ }^{7}$. However, the combined use of these techniques with modern solutions, such as monopolar radiofrequency, botulinum toxin, and fillers ${ }^{8}$, can lead to results that are very similar to those obtained with classic surgical treatments (facelift), with less hassles and without the risks of the operation.

The treatment is based on two important points: the diagnosis of the facial requirements and the combination of two or more minimally invasive techniques to obtain the desired result. This paper describes the suspension thread as a key element in achieving these results. To treat the problems found on the face, there is a combination of therapies, in which suspension plays a prominent role. This technique allows recovery of a younger facial anatomy. The technique is a modification of endoscopic suspension ${ }^{9}$, promoting traction of the midface through dermomuscular interaction. It is a minimally invasive procedure performed on an outpatient basis under local anesthesia, with low morbidity and rapid recovery, allowing patients to return to their daily activities almost immediately after the procedure.

\section{METHODS}

The study included 50 female patients aged 39 to 68 years who were operated on between December 2008 and June 2010.
Surgical materials developed by the authors of this work were used to carry out musculoaponeurotic suspension with minimally invasive periosteal fixation of the middle third of the face. These materials include needles that can be sterilized in an autoclave. The needles have specific tips for each passage of the thread, depending on the surgical plan, and a center hole for driving the thread (Figure 1). These characteristics are necessary for performing the procedure. Polypropylene suture with a resistance index 0 or 1, usually available in the hospital environment, is used. This type of suture has the advantages of being non-absorbable and easily accessible in case removal is necessary.

Initially, the insertion points of the temporalis muscle on the skull are identified. These are points 1 and 2, which are the points of support of the suspension. These points are localized by asking the patient to tighten the lower jaw against the upper jaw (biting with a shut mouth), allowing the observer to see the contraction of the temporalis muscle. In the next step, point 3, the largest suspension point of the face, and point 4 , the anchor point, are identified. Importantly, these points should be parallel to produce maximum suspension (Figure 2). Subsequently, asepsis of this region is achieved using povidone-iodine antiseptic detergent or $70 \%$ alcohol, followed by local anesthesia between points by injecting $5 \mathrm{ml}$ of $2 \%$ xylocaine combined with a adrenaline as a vasoconstrictor. With the aid of a $40 \times 12$ needle, small holes are made in the locations, which are then dilated with a blunt needle. The passage of the thread starts intramuscularly at point 1 , using a blunt needle, moving in a zigzag pattern toward

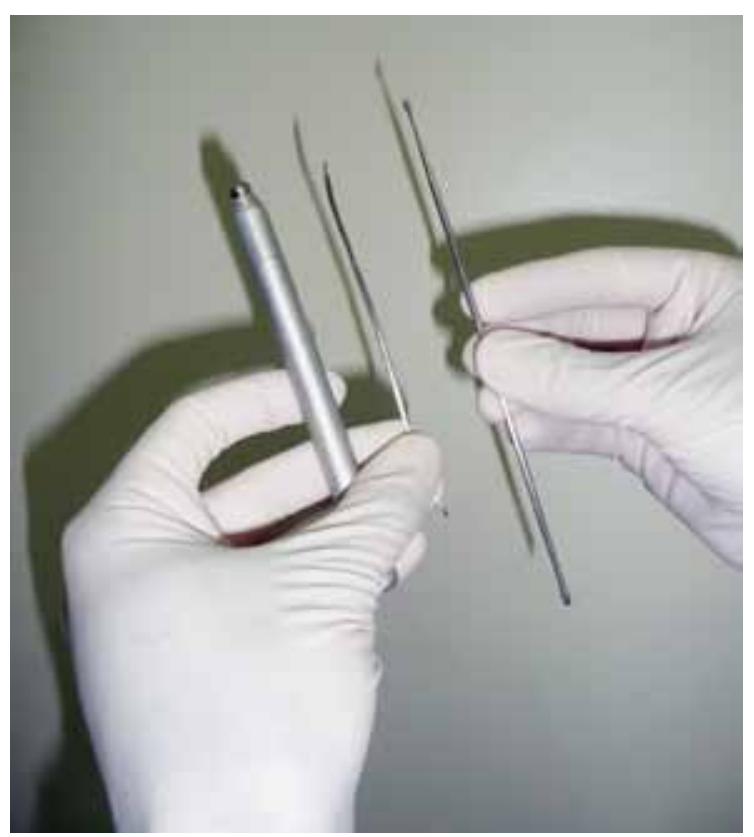

Figure 1 -Needles made by the authors to pass the thread. 
the second point. At this point, the needle moves outward (Figures 3 to 5). Between points 2 and 3, the blunt needle and thread pass through the subdermal plane, causing more traction and lifting the middle third of the face (Figure 6).

Between points 3 and 4 , the thread is passed in a zigzag pattern through the intramuscular plane, avoiding the superficial temporal artery, which is exteriorized. Finally, between points 4 and 1 , the blunt needle is replaced by a flat-tipped needle, which passes through the subperiosteal plane, serving as a reference for traction. Figures 7 and 8 illustrate the dissected region and the passage of the thread (in cadavers).

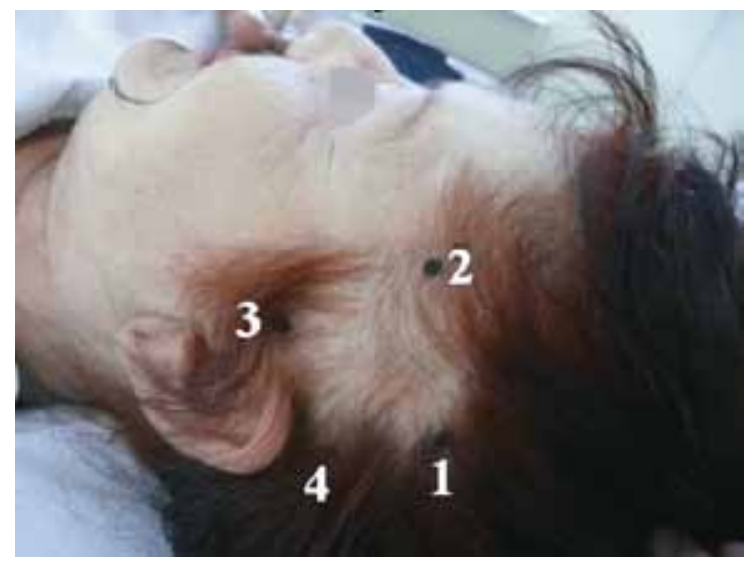

Figure 2 - Reference points in the temporal region, as described in the text.

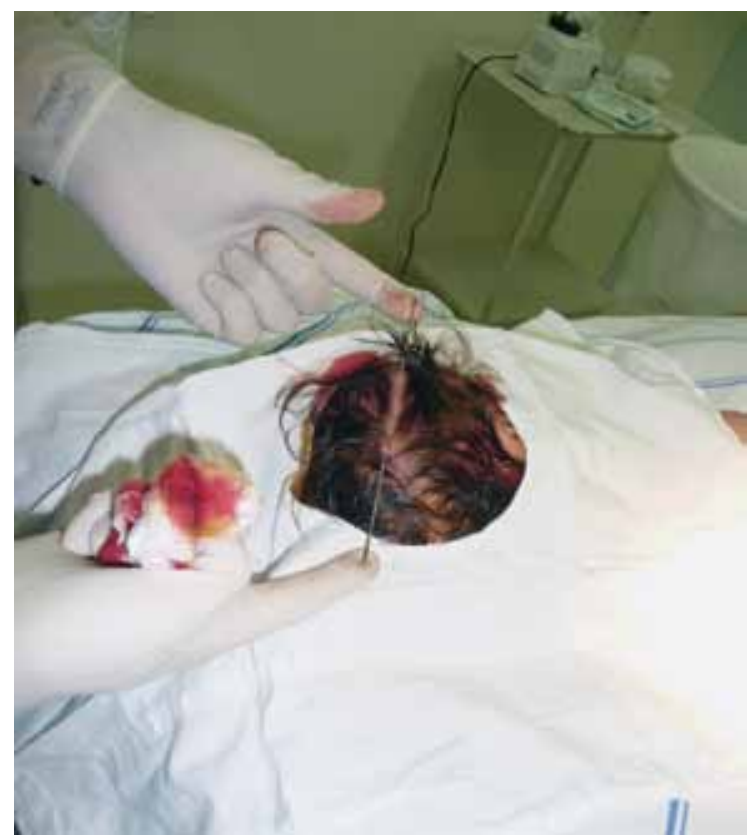

Figure 3 - Needle with the thread passing between points 1 and 2 (right side).
After passing the thread, traction is carried out up to the point where progression of tissue is possible, with a minimum of 5 or 6 knots. A synthetic monofilament thread is suitable for this application. The result is obtained immediately, and it is not a rare practice to show the difference between treated and untreated sides to the patient, with the aid of a mirror (Figure 9).

The same procedure is performed contralaterally, and the average time required to complete both sides is 30 minutes. In the end, the holes should be inspected to ensure that no hair has been included in the needle insertion sites, because this increases the risk of developing local granulomas. Gentle pressure is applied over the region for 5 minutes to prevent bleeding. Some increased volume is usually reported in the hair area, and this resolves within 40 days after the procedure. During this period, arrangement of tissues also occurs. The patient can return to his daily activities on the same day of the procedure. Some suspension procedures are performed

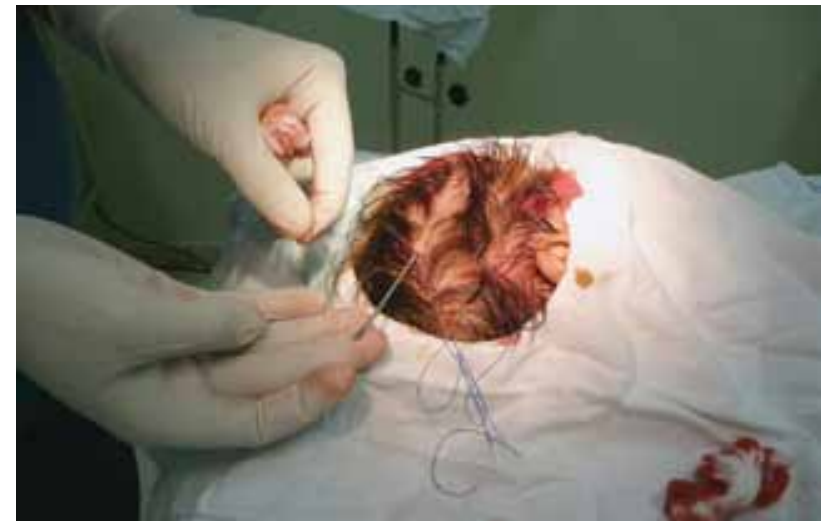

Figure 4 - Needle with the thread passing between points 1 and 2 (left side).

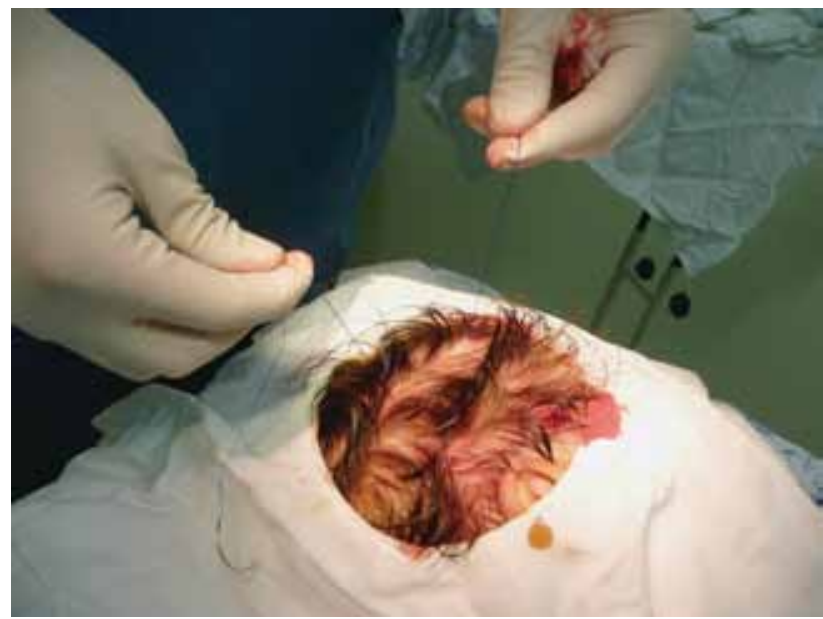

Figure 5 - Thread passing between points 1 and 2 (right side). 


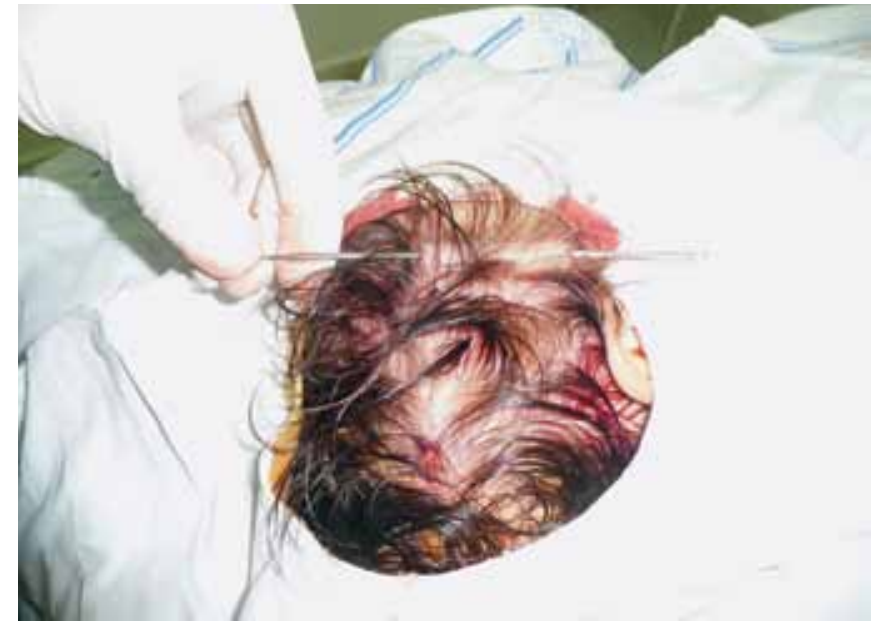

Figure 6 -Needle passing between points 2 and 3 (right side).

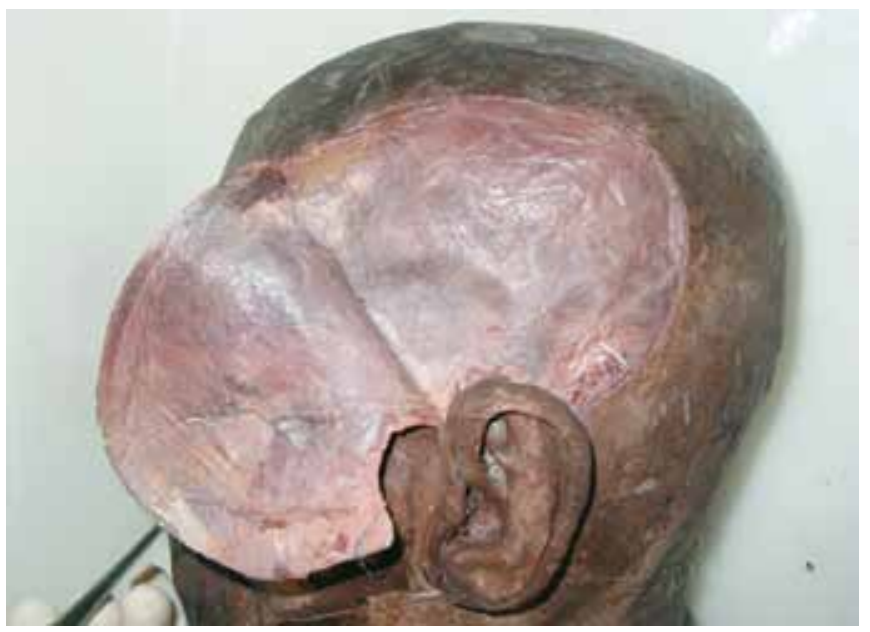

Figure 7 - Picture of a cadaver showing the skin of the retailed temporal region.

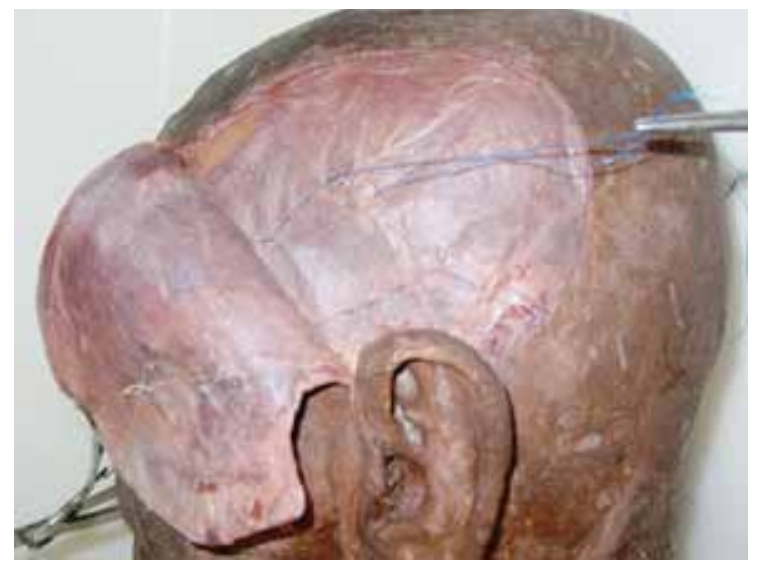

Figure 8 - Picture of a cadaver showing the skin of the retailed temporal region with the placed thread. separately, others using a combination of different techniques and minimally invasive treatments, such as botulinum toxin, fillers, monopolar radiofrequency, and peeling.

The degree of patient satisfaction with the procedure used in this study was assessed with the aid of a questionnaire.

\section{RESULTS}

During the 18-month follow-up period, the results were satisfactory. The degree of patient satisfaction with the results, especially in the first six months after the procedure, was extremely high and exceeded the authors' expectations. In the questionnaire, answered by 50 patients, $88 \%$ rated the result as good/excellent, a result superior to the authors' evaluation of the results of this study (78\%).

There was a significant reduction in the aging signs on the midface, which exhibited a natural aspect.

Serious complications were observed in this series of patients. A small area of alopecia, which looked like a band, was observed on the path of the thread in one patient, and it vanished spontaneously later. Another patient, with a history of migraine, had severe pain in the first three days after the procedure. Pain was controlled with analgesics, and thread removal was not necessary. Two patients had granuloma in the hole connecting the thread to point 1 . Mild local irritation associated with elevation of the hair area was reported in most of the patients. This did not interfere with routine functions and resolved spontaneously within 40 days (Figures 10 and 11).

\section{DISCUSSION}

In modern society, people are increasingly looking for well-being and quality of life. Within this concept, facial appearance occupies an important role in the impressions made on personal contacts.

Traditional surgical procedures performed on the face, especially surgical facelifts, produce exceptional results when properly indicated and performed. However, in most cases, these procedures are associated with high cost, temporary cessation of activities, and inherent risks of the surgical procedure. Moreover, very impressive results on the face are not desired by many patients who seek natural rejuvenation without substantially changing their features.

Based on these premises, minimally invasive procedures have gained much attention in facial rejuvenation involving the skin, muscles, and connective tissue. The ability to offer patients a low-risk procedure at lower cost with less radical, gradual results and without a long recovery period has caught the attention of a large percentage of physicians. Prospective patients are usually very active, with busy social and professional lives, and seek attenuation of the signs of facial aging to improve quality of life. 

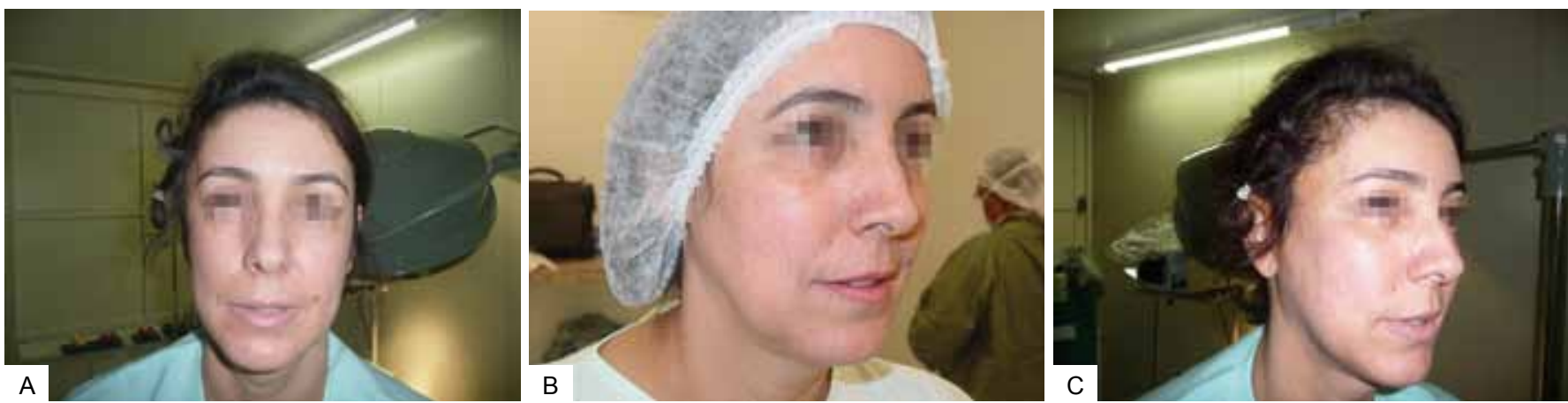

Figure 9 - In A, front view of a patient who underwent placement of a thread on the right side (left side not yet treated). In $\boldsymbol{B}$, right lateral view of a patient before suspension with the thread. In $\boldsymbol{C}$, right lateral view of a patient immediately after suspension with the thread.
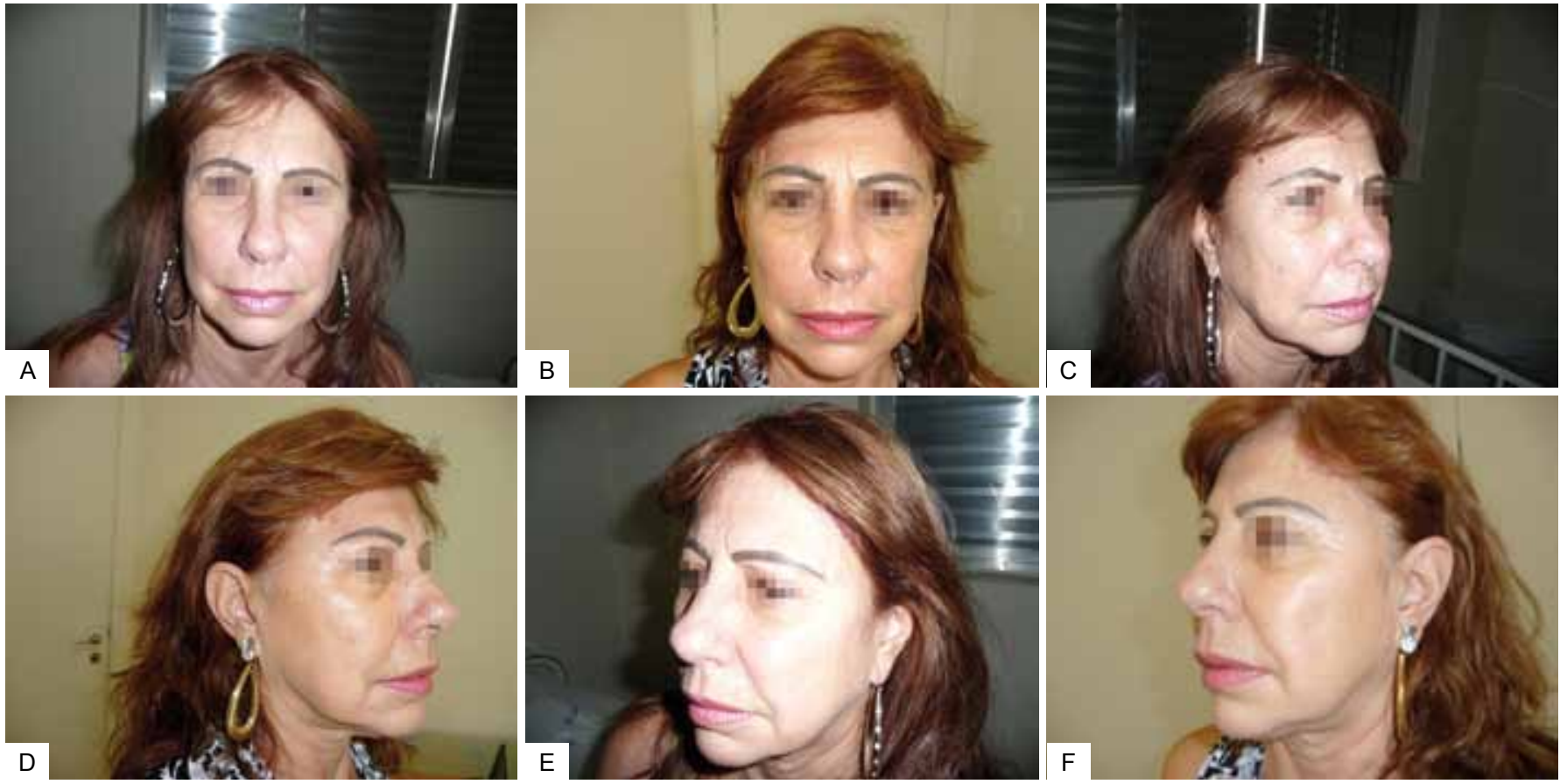

Figure 10 - In A, front view of a patient before suspension with the thread. In $\boldsymbol{B}$, frontal view of a patient three months after suspension with thread. In $\boldsymbol{C}$, right lateral view of a patient before suspension with the thread. In $\boldsymbol{D}$, right lateral view of a patient three months after the suspension with thread. In $\boldsymbol{E}$, left lateral view of a patient before suspension with thread. In $\boldsymbol{F}$, left lateral view of a patient three months after suspension with the thread.

Traction of the midface with a thread, as described in this article, fits into the concept of minimally invasive cosmetic procedures and represents another therapeutic option for doctors. This option is especially well suited for patients who do not want or cannot undergo a traditional lift. Combined with other procedures, such as use of botulinum toxin, fillers, and peeling, the technique described in this study produces results very close to those of the traditional facelift, with the advantage of an almost immediate recovery.
The execution of the procedure is relatively simple and relies on the use of appropriate materials and environment. Preoperative preparation of the patient is not necessary, and the procedure can be performed in an outpatient clinic (level I surgery).

Regarding the results, there is greater enthusiasm for this procedure among patients than among doctors. This may be because patients have, in addition to improved esthetics, a feeling of tension in their face, described by patients as more firmness in the tissues of the middle third of the face. 

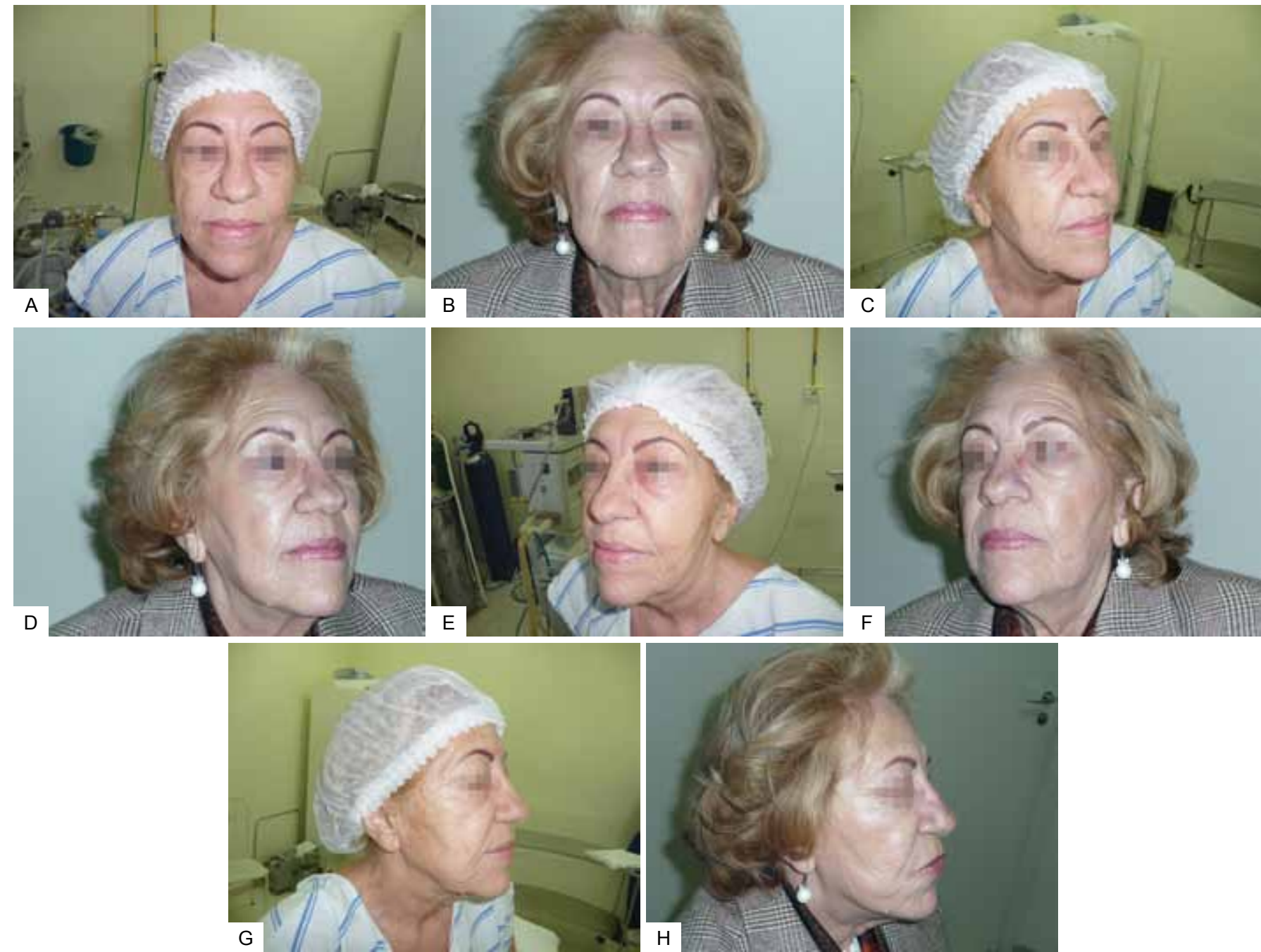

Figure 11 - In A, front view of a patient before suspension with thread. In $\boldsymbol{B}$, frontal view of a patient six months after suspension with the thread. In $\boldsymbol{C}$, right lateral view of a patient before suspension with thread. In $\boldsymbol{D}$, right lateral view of a patient six months after suspension with thread. In $\boldsymbol{E}$, left lateral view of a patient before suspension with thread. In $\boldsymbol{F}$, left lateral view of a patient six months after suspension with thread. $\boldsymbol{G}$, right profile of a patient before suspension with thread. $\boldsymbol{H}$, right profile of a patient six months after suspension with thread.

As observed for the traditional facelift, the proposed procedure works better when conducted on thin individuals and individuals with long faces, described as patients with a light middle third facial flap. Patients with shorter or full faces present more inconspicuous results.

The postoperative follow-up of patients in this study showed maintenance of the results for a period of 18 months, which is quite reasonable for a minimally invasive procedure. The complication rate was very low in this series, merely a case of traction-related alopecia with spontaneous recovery, a case of migraine controlled with analgesics, and two cases with small granulomas in the region of point 1 , which showed resolution on medical treatment (antibiotics and topical treatment with zinc oxide). One patient underwent removal of the thread from the right side, with subsequent placement of another thread in the same place, without compromising the result.

\section{CONCLUSION}

With the combined use of minimally invasive procedures on the face and a suspension thread for the middle third of the face as the most relevant element, it may be possible to achieve results that are very similar to those of the traditional facelift, with all the advantages already mentioned. In the future, facelift techniques will move toward non-surgical procedures. The present procedure provides good results, without incisions or sutures, and a short recovery period, 
allowing patients to return to their daily activities almost immediately. This technique has advantages over current techniques that use thread, since it does not invade the area of the face. The musculoaponeurotic suspension with periosteal fixation technique significantly increases the duration of the outcome and reduces morbidity and recovery time. Finally, unlike traditional techniques, the procedure can be fully reversed by simply removing the thread. This technique is not intended to replace conventional rhytidoplasty but seems to be a very useful tool in patients who do not want or cannot undergo conventional rhytidoplasty. This technique may also be very useful for improving the outcome of traditional rhytidoplasties and blepharoplasties.

\section{REFERENCES}

1. Obagi ZE. Restauração e rejuvenescimento da pele. Trad. De Souza AST. Rio de Janeiro: Revinter; 2004. p.45-51.
2. Obagi ZE. Obagi skin health restoration and rejuvenation. Nova York: Spring-Verlag; 1998. p.11-3.

3. De Souza A. Antiaging, beleza e juventude em qualquer idade. São Paulo: Alaude; 2010. p.74.

4. Williams EF $3^{\text {rd }}$, Smith SP Jr. Minimally invasive midfacial rejuvenation: combining thread-lift and lipotransfer. Facial Plast Surg Clin North Am. 2007;15(2):209-19.

5. Sulamanidze MA, Fournier PF, Paikidze TG, Sulamanidze GM. Removal of facial soft tissue ptosis with special threads. Dermatol Surg. 2002;28(5):367-71.

6. De Souza A. Christiansen C, Jamie S. The use of salicylic acid in a new delivery system as a co-adjuvant topical treatment for acne vulgaris. Aesthet Surg J. 2005;25(1):40-3.

7. Doshi SN, Alster TS. Combination radiofrequency and diode laser for treatment of facial rhytides and skin laxity. J Cosmet Laser Ther. 2005;7(1):11-5.

8. Gold MH, Goldman MP. 5-aminolevulinic acid photodynamic therapy: where we have been and where we are going. Dermatol Surg. 2004;30(8):1077-83.

9. De Souza A, Tai PL. Novos princípios em cirurgia plástica não invasiva e medicina anti-aging. São Paulo: Santos Editora; 2010. p.89-98.

\section{Correspondence to:}

João Carlos Cisneiros Guedes de Andrade Júnior

Rua Primavera, 112 - ap. 302 - Santo Antônio - Belo Horizonte, MG, Brazil - CEP 30330-260

E-mail: jccisneiros@brfree.com.br 